Canadian Journal of Fisheries and Aquatic Sciences Journal canadien des sciences halieutiques et aquatiques

\title{
Predicting the impacts of escaped farmed Atlantic Salmon \\ on wild salmon populations
}

\begin{tabular}{|c|c|}
\hline Journal: & Canadian Journal of Fisheries and Aquatic Sciences \\
\hline Manuscript ID & cjfas-2017-0386.R1 \\
\hline Manuscript Type: & Rapid Communication \\
\hline Date Submitted by the Author: & 01-Dec-2017 \\
\hline Complete List of Authors: & $\begin{array}{l}\text { Keyser, Freya; Northwest Atlantic Fisheries Centre, Fisheries and Oceans } \\
\text { Canada } \\
\text { Wringe, Brendan; Northwest Atlantic Fisheries Centre, Fisheries and } \\
\text { Oceans Canada; Memorial University of Newfoundland Department of } \\
\text { Biology } \\
\text { Jeffery, Nicholas; Northwest Atlantic Fisheries Centre, Fisheries and Oceans } \\
\text { Canada; Dalhousie University Department of Biology } \\
\text { Dempson, J. Brian; Northwest Atlantic Fisheries Centre, Fisheries and } \\
\text { Oceans Canada } \\
\text { Duffy, Steven; Northwest Atlantic Fisheries Centre, Fisheries and Oceans } \\
\text { Canada } \\
\text { Bradbury, Ian; Northwest Atlantic Fisheries Centre, Fisheries and Oceans } \\
\text { Canada; Memorial University of Newfoundland Department of Biology; } \\
\text { Dalhousie University Department of Biology }\end{array}$ \\
\hline \multirow[t]{2}{*}{$\begin{array}{r}\text { Is the invited manuscript for } \\
\text { consideration in a Special } \\
\text { Issue? : }\end{array}$} & $\mathrm{N} / \mathrm{A}$ \\
\hline & $\begin{array}{l}\text { ENVIRONMENTAL IMPACT < General, SPATIAL ANALYSIS < General, Salmo } \\
\text { salar, Population genetics, Aquaculture environment interactions }\end{array}$ \\
\hline
\end{tabular}

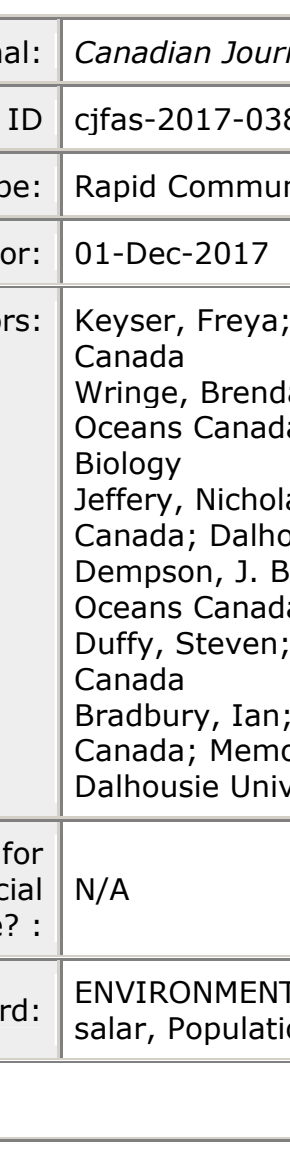

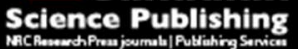


"Corresponding author: Ian Bradbury, Northwest Atlantic Fisheries Centre, Fisheries and Oceans Canada, St. John's, NL A1C 5X1. Phone: 709-772-3869, fax: 709-772-4188

Freya Keyser ${ }^{1}$, Brendan F. Wringe ${ }^{1,2}$, Nicholas W. Jeffery ${ }^{1,3}$, J. Brian Dempson ${ }^{1}$, Steven Duffy $^{1}$, and Ian R. Bradbury ${ }^{* 1,2,3}$

${ }^{1}$ Northwest Atlantic Fisheries Centre, Fisheries and Oceans Canada, St. John's, NL A1C $5 \mathrm{X} 1$

${ }^{2}$ Memorial University of Newfoundland, St. John's, NL A1C 5S7

${ }^{3}$ Dalhousie University, Halifax, NS B3H 4R2

Emails:

freya.keyser@dfo-mpo.gc.ca

brendan.wringe@dfo-mpo.gc.ca

nick.jeffery@dfo-mpo.gca.ca

brian.dempson@dfo-mpo.gc.ca

steven.duffy@dfo-mpo.gc.ca

ian.bradbury@dfo-mpo.gc.ca

34 


\section{Abstract}

The escape of Atlantic Salmon (Salmo salar) from aquaculture facilities can result in both negative genetic and ecological interactions with wild populations, yet the ability to predict the associated risk to wild populations has remained elusive. Here we assess the potential of a spatiotemporal database of aquaculture facility locations, production estimates and escape events to predict the distribution of escaped farmed salmon and genetic impacts on wild populations in the Northwest Atlantic. Industry production data, reported escape events, and in-river detections of escaped farmed salmon were collected from across the Northwest Atlantic. Genetic estimates of impact were obtained using single nucleotide polymorphisms (95 loci) representing aquaculture and wild salmon throughout the region (30 populations, 3048 individuals). Both the number of escaped farmed salmon detected at counting facilities and the magnitude of genetic impacts were positively correlated with a cumulative spatial measure of aquaculture production. Our results suggest that the risk of escapees and genetic introgression from wild-farmed salmon interactions can be assessed using information on farm production characteristics. This represents a first step in predicting the impact of existing cage-based farms on wild Atlantic salmon. 


\section{Introduction}

55 The Atlantic Salmon (Salmo salar) is one of the most valuable aquaculture fish species

56 and the salmon aquaculture industry is expanding worldwide (FAO 2016). Despite

57 continued refinement of production methods and technology, the escape of aquaculture

58 individuals into the wild environment occurs regularly due to weather events, predator

59 attacks, or losses during regular operations (Bentsen and Thodesen 2005; Glover et al.

60 2017; Jensen et al. 2010). Estimates suggest two million farmed Atlantic Salmon escape

61 into the North Atlantic Ocean every year (Schiermeier 2003) with negative evolutionary

62 and ecological impacts on wild salmon populations (Bolstad et al. 2017; Fleming et al.

63 2000; McGinnity et al. 2003; Skaala et al. 2012; Weir et al. 2005). Farmed salmon are

64 both genetically distinct (reviewed by Glover et al. 2017), and phenotypically divergent

65 from wild salmon, with differences such as accelerated growth rates, delayed maturity,

66 behavioural differences and reduced immunity (Fleming et al. 1996; Jonsson and Jonsson

67 2006), contributing to reduced survival in the wild (Fleming et al. 2000; McGinnity et al.

68 2003; McGinnity et al. 1997; Skaala et al. 2012). Interbreeding between escaped farmed

69 salmon and wild salmon has been widely documented (Bourret et al. 2011; Clifford et al.

70 1998; Crozier 1993; Glover et al. 2013; Glover et al. 2012; Karlsson et al. 2016; Skaala et

71 al. 2006) and can lead to phenotypic changes in native wild populations (Bolstad et al.

72 2017; Fraser et al. 2010), which in turn can reduce the fitness of wild populations (Fraser

73 et al. 2008; McGinnity et al. 2003; Verspoor et al. 2015). Although interactions between

74 wild and escaped domestic Atlantic Salmon have repeatedly been identified as significant

75 threats to the persistence of wild populations (COSEWIC 2010; DFO 2008; DFO 2013;

76 Forseth et al. 2017; USASAC 2016), methods to predict and mitigate impacts remain 77 lacking.

78 Wild Atlantic Salmon populations in the Northwest Atlantic have declined in

79 recent decades (Chaput 2012; ICES 2016) resulting in the closure of both commercial and

80 recreational fisheries (COSEWIC 2010; DFO 2008; DFO 2013; USASAC 2016). The

81 factors responsible for these declines likely vary across regions (COSEWIC 2010; Parrish

82 et al. 1998), however, genetic interaction with escaped farmed salmon has been identified

83 as a major concern (DFO 2013; Ford and Myers 2008; Verspoor et al. 2015). Previous

84 attempts to quantify the frequency of escape events and distribution of escaped farmed 
salmon in rivers have been limited, but available data suggest they are present in the majority of rivers near $(<300 \mathrm{~km})$ the industry in Atlantic Canada (Morris et al. 2008). Moreover, recent genomic evidence indicates significant hybridization between wild and farmed salmon has occurred in southern Newfoundland (Wringe et al. in review), which may further negatively affect threatened wild salmon populations (COSEWIC 2010; DFO 2013). Despite continued evidence of genetic impacts on wild salmon populations (Bolstad et al. 2017; Bourret et al. 2011; Clifford et al. 1998; Crozier 1993; Fraser et al. 2008; Fraser et al. 2010; Glover et al. 2013; Glover et al. 2012; Karlsson et al. 2016; McGinnity et al. 2003; Skaala et al. 2006; Verspoor et al. 2015) the ability to predict population-level risks to inform management efforts remains limited. Predictive models linking aquaculture industry production characteristics, the distribution of escaped farmed salmon, and impacts on wild populations are ultimately needed to assess and manage risks to wild Atlantic Salmon. A first step in developing these predictive models is to identify variables that are associated with the distribution of escaped farmed salmon or associated impacts on wild populations. of escaped farmed salmon in Atlantic Canada and the genetic risk from escaped farmed salmon to wild salmon populations. Results could be used to inform aquaculture management regarding the conservation of wild populations. Specifically, we explored the ability of a spatiotemporal database of aquaculture facility and production data to predict (1) the distribution of escaped farmed salmon and (2) the genetic impacts on wild populations in Atlantic Canada. This work builds on the database and analysis published

\section{Methods}

\section{Data retrieval and sampling}

113 Data compiled for this study were of three types: (1) aquaculture site production 114 and location data for the Northwest Atlantic region; (2) reports of escaped farmed salmon 115 in Northwest Atlantic rivers (Table S1); (3) population genetic estimates of introgression 
116 between wild and farmed Atlantic Salmon from southern Newfoundland. For the 117 aquaculture site locations and production data, the resolution of available information 118 differed by jurisdiction, so analyses were designed to address any associated assumptions 119 and limitations due to these differences. The numbers listed below represent all licensed 120 aquaculture sites in Newfoundland, New Brunswick, Nova Scotia and Maine for the 121 period of 2005-2015. Inventory data were obtained for a total of 78 aquaculture sites in 122 Newfoundland from the period of 2005-2015 (provided by G. Perry, Aquaculture 123 Management, Newfoundland Region, Fisheries and Oceans Canada (DFO); Fig S1A). 124 Using the reported information on farm-stocked fish (e.g. introductions, transfers, harvest 125 numbers, and mortalities), an annual estimate of the average number of fish per site was 126 calculated. For the province of New Brunswick, data were obtained during annual provincial monitoring activities (i.e. actual counts of fish in cages on the day of 129 (i.e. the maximum number a site is permitted to stock annually) were available for 20051302012 (provided by T. Lyons, New Brunswick Department of Environment and Local 131 Government, and G. Cline, Aquaculture Management, Maritimes Region, DFO). Detailed 132 inventory data for Nova Scotia were not available at the time of analysis so annual 133 stocking license information for 18 sites during the years 2005-2015 were used (provided 134 by E. Parker, Aquaculture Management, Maritimes Region, DFO). Annual stocking 135 license data from 17 sites in Maine were also available for 2005-2015 (provided by D. 136 Bean, National Marine Fisheries Service, National Oceanic and Atmospheric 137 Administration).

138 Due to discrepancies in aquaculture production monitoring between 139 provinces/states, for all region-wide analyses, specific production numbers were not 140 involved. Instead, each aquaculture site was assigned a value depending on whether it 141 was fallow (0) or stocked (1) for each year. For analyses including genetic data (see 142 below), the spatial extent was restricted to Newfoundland so that annual estimates of fish 143 per site could be used. Further details are provided in analysis section below.

144 Reports of escaped farmed salmon detected in rivers throughout the study region 145 were obtained via opportunistic surveys and dedicated sampling and monitoring 146 programmes (Table S1; Fig S1B), as in Morris et al. (2008). Academic and governmental 
147 Atlantic Salmon research programmes, aquaculture management authorities, and

148 conservation organizations (e.g., Atlantic Salmon Federation) were asked to provide

149 information on any escaped farmed salmon encountered. New reports of river-specific

150 presence (with counts when available) or absence were added to the database compiled

151 by Morris et al. (2008). Additional records were obtained from monitoring facilities

152 (counting fences) in the Magaguadavic River in NB (since 2002), and Garnish River

153 (since 2015) and Conne River in NL (since 1987). Scientific gillnetting and angling were

154 also conducted in several Newfoundland rivers during the fall seasons of 2015 and 2016.

\section{Genetic analysis}

Genetic analysis was used to quantify the degree of introgression between escaped farmed salmon and wild populations in southern Newfoundland. Data examined included a combination of previously published sources including: (1) single nucleotide polymorphism (SNP) array data (Bradbury et al. 2015; Moore et al. 2014; Wringe et al. in review), and (2) targeted genotyping of a subset of this larger array using a 96 SNP assay

163 Genomics (CIGENE, Norway) (Bourret et al. 2013a; Bourret et al. 2013b) was used for

164611 individuals from the Maritimes and southern Newfoundland. For the targeted genotyping of 96 SNPs (Wringe et al. in review) a further 2703 individuals from southern

166 Newfoundland were genotyped. The total SNP data set was comprised of a total of 3314

167 individuals, including 156 individuals (adults) of known aquaculture ancestry, and from

16847 Atlantic Salmon populations wild Maritimes and southern Newfoundland, plus two

169 aquaculture populations. 15 rivers from southern Newfoundland had data for two years

170 (2014 and 2015), providing a total of 64 populations spanning the Maritimes and

171 southern Newfoundland. Results presented here are limited to southern Newfoundland

172 populations $(n=26)$.

173 The methodology for the 5568 SNP array is described in detail in Bradbury et al.

174 (2015). In summary, only SNP genotypes with a call rate greater than 0.95 were retained

175 and SNPs were removed where minor allele frequencies were $<0.05$, or were missing in

$176>0.15$ of individuals. For the targeted genotyping of the subset of 95 SNPs, SNP Type

177 assays (Fluidigm) per the manufacturer's protocols were used (Wringe et al., in review). 
178 This SNP genotyping was performed using 96.96 genotyping Integrated Fluidic Circuits, 179 read on an EP1 (Fluidigm) and analyzed using SNP Genotyping Analysis software 180 (Fluidigm). Based on reanalysis of samples and following Pompanon et al. (2005), the 181 genotype error rate was calculated to be $0.01 \%$ and consistent with other studies (0 $1820.2 \%$, see Hess et al. (2015), Jones et al. (2015), Larson et al. (2014), Petrou et al. (2014), 183 Seeb et al. (2009)).

184 We used the Bayesian clustering software STRUCTURE (Pritchard et al. 2000) to 185 estimate population admixture values between domestic and wild populations (i.e. Q186 values ranging from 0 to 1 respectively). The R package ParallelStructure (Besnier and 187 Glover 2013) was used to estimate K, the putative number of populations, from 1-30, 188 replicated three times each. Each run had a burn-in of 100,000 Markov chain iterations, 189 followed by 500,000 iterations. STRUCTURE was run with the admixture model and 190 without population location priors. The degree of introgression with escaped farmed 191 salmon was then calculated based on the mean proportion of each population's genome 192 that could be attributed to the domestic baseline population.

\section{Spatial analysis: Propagule pressure}

The river-specific risk from escaped farmed salmon was spatially quantified using propagule pressure, adapted from invasive species research where it represents the

197 intensity of anthropogenic introductions of non-native species (Colautti 2005; Consuegra 198 et al. 2011; Copp et al. 2007). In this study, propagule pressure was calculated for each 199 river as either the presence of fish at an aquaculture site each year (from 2005-2015), or 200 the number of fish stocked each year, divided by the distance to that site, and summed 201 across all sites and years. For fine-scale analyses involving only Newfoundland, annual 202 estimates of the number of fish per aquaculture site were divided by their respective 203 distances to each river. That is:

$$
\text { Propagule pressure for a given river }(R)=\sum_{i, y=1}^{S} \frac{F_{i, y}}{L C D\left(S_{i, y} \text { to } R\right)}
$$

204 where $S_{i, y}$ represents an aquaculture site in a given year $(y), R$ each river, $F_{i, y}$ the number 205 of fish at site $S_{i}$ each year OR presence of fish in aquaculture site $S_{i}$ each year (0 or 1$)$, 206 and $L C D$ represents the least-cost distance function. 
For region-wide analyses, as numbers of stocked fish were not available for all jurisdictions, a value of one was assigned to aquaculture sites that were stocked in a given year, and unstocked sites were excluded $(0 / \mathrm{LCD}=0)$. The propagule pressure variable allows a river-specific measurement of aquaculture intensity that relates to both the proximity of aquaculture sites and the production levels of the sites. As such, rivers that

212 were close to many aquaculture sites or close to a few very high-production sites would

213 have stronger propagule pressures than rivers that were far from aquaculture sites or only

214 near smaller-scale production sites. Propagule pressures were calculated for all rivers in

215 the compiled escaped farmed salmon database, and any rivers with genetic data,

216 including Maritimes rivers reported in Moore et al. (2014) that were not included in this

217 study's analyses (Fig S3).

218 To explore the utility of propagule pressure in predicting aquaculture impacts,

219 three measures of impact were derived from the collated data: the presence of escaped

220 farmed salmon in rivers, the number of escaped farmed salmon in rivers, and the amount

221 of introgression observed in populations as reflected by the population mean Q-values

222 resulting from the Newfoundland STRUCTURE analysis (see above). Log-log regression

223 models and GLMs (using Poisson and binomial distributions) were applied to examine

224 the relationship between propagule pressure and these measures of impact. T-tests and/or

225 Chi-square tests were used to assess the significant effects of explanatory variables on the 226 measures of impact. AIC (Akaike information criterion), or corrected Akaike information 227 criterion, (AICc), where appropriate were used to compare and weight models according 228 to their fit to the data and complexity. River size (measured as axial distance in 229 kilometres) was also used as an explanatory variable to address the influence of 230 population size. The R statistical environment (version 3.3.2; R Development Core Team 231 2016) and RStudio (version 1.0.136; RStudio Team 2015) were used for all visual and 232 statistical analyses. Maps were produced using shapefiles downloaded from GADM.org 233 via package raster. A package containing a function to calculate propagule pressure was 234 written to facilitate this analysis and is available for download from GitHub via GNU 235 General Public License (Package AQpress: https://github.com/freyakeyser/AQpress).

\section{Results}


In total, an additional 217 records were added (annual river reports of escaped

239 farmed salmon presence or absence) to the Morris et al. (2008) adult farmed escapee

240 database, for a grand total of 467 records from the 1980s to 2016 (Table S1). New

241 records of presence or absence of escaped farmed salmon for 17 rivers for which no

242 information previously existed were collected (mostly in Newfoundland; Morris et al.

243 (2008) only presented records for two rivers in NL), as well as new records of presence or

244 absence for a separate 17 rivers already in the Morris et al. (2008) database. These

245 additions bring the total number of rivers in the database to 112 rivers (Table S1). A total

246 of 1091 escaped farmed salmon have been detected since the publication of the (Morris et

247 al. 2008) database, and our updated database contains detections of 9236 escaped farmed

248 salmon in Northwest Atlantic rivers. Rivers in the Passamaquoddy Bay (outer Bay of

249 Fundy) area had higher numbers of escaped farmed salmon reported than other areas (Fig

250 S1B). In addition to the database of escaped farmed salmon reports, this study also

251 incorporated genetic information for 29 Newfoundland rivers (Fig S1A; Fig S3; Table

252 S2).

253 The presence of escaped farmed salmon in each river based on all data including

254 opportunistic, standardized sampling data, and reports of escaped farmed salmon in each

255 river $(\mathrm{p}$-value $=0.717, \mathrm{AIC}=35.7$, null deviance $=31.8)$ were not significantly

256 correlated with region-wide propagule pressures (Table S3; Fig S4; Table S4; Fig S5).

257 The total number of escaped farmed salmon detected using all data was significantly

258 related to propagule pressure ( $\mathrm{p}$-value $<0.05$, Table $\mathrm{S} 4)$, although very few data points

259 fell within the model's 95\% confidence interval (Fig S5, AIC $=3671.024$, null deviance $=$

260 3687.0). However, when only counting fence or fishway counts were used in the GLM

261 (Poisson distribution), there was a significant positive exponential effect of propagule

262 pressure ( $\mathrm{p}$-value $<0.001$ ) on the number of escaped farmed salmon in rivers, and the

263 model fit was improved with AIC of 1064.5 and null deviance of 1941.7 (Fig 1A; Table

264 S5). The removal of the reports from Magaguadavic River (an outlier value with 379

265 escaped farmed salmon detected) did not change this effect, though the AIC decreased to

266213.5 (Fig 1B; Table S5).

267 Individual Q-values for wild-collected Newfoundland samples ranged from 0.006

268 to 0.990 (Fig S6), representing both pure wild individuals (0) and pure aquaculture 
individuals (1). Population mean Q-values ranged from 0.028 to 0.737, and rivers in Bay d'Espoir and Fortune Bay generally had higher Q-values than other rivers. Most (70 \%) of the wild Newfoundland individuals had Q-values $<0.5$ (Fig S6). There was a significant positive log-log relationship ( $p$-value $<0.01, R^{2}=0.279$ ) between population mean Q-value and localized propagule pressures in Newfoundland (Fig 2A; Table S6), and a weak negative log-log relationship ( $\mathrm{p}$-value $>0.05, \mathrm{R}^{2}=0.071$ ) between population mean Q-value and river size, measured as axial distance in kilometres (Fig 2B; Table S6). A GLM using both propagule pressure and river size ( $\mathrm{AIC}=73.1$, null deviance $=26.8$ ) identified a significant $\log$-log effect of propagule pressure $(p$-value $=0.018)$ on population mean Q-value, but no significant effect of river size ( $\mathrm{p}$-value $=0.274$, Table S7), and model comparisons using AICc determined that the strongest model for population mean Q-value did not include river size as an explanatory variable (Table S6).

\section{Discussion}

Escaped farmed Atlantic Salmon have been associated with both negative genetic and ecological interactions with wild populations (Bolstad et al. 2017; Glover et al. 2017; Verspoor et al. 2015). Accordingly, the ability to predict risk to wild populations is central to wild salmon conservation and aquaculture management. We evaluated the utility of industry production data and reported escape events to predict the distribution of escaped farmed salmon and the genetic impacts on wild populations in the Northwest Atlantic. Results indicated that increased numbers of escaped farmed salmon detected at counting facilities and an increased magnitude of genetic impacts in wild populations were both positively correlated with increased propagule pressure. These relationships suggest that the location and size of aquaculture facilities directly affects the magnitude of risk to wild salmon populations from escaped farmed salmon. Characterizing this risk represents an important step toward predicting the impact of cage-based Atlantic Salmon aquaculture on wild Northwest Atlantic Salmon populations. Relationships between the magnitude of aquaculture production and escaped farmed salmon occurrence and impacts have been previously observed in the Northeast (Fiske et al. 2006; Hansen et al. 1999), and Northwest Atlantic (Carr et al. 1997), but spatial variables have not been considered. This work extends previous studies that have documented the distribution of escaped 
300 farmed salmon in Atlantic Canada (Morris et al. 2008) and provided evidence of 301 hybridization and introgression among wild and farmed salmon following escape events

302 (Wringe et al., in review) by using these data sources to test a novel approach to predict 303 future impacts.

304 Escaped farmed salmon have been detected everywhere net-pen salmon 305 aquaculture occurs with reports of millions of individuals escaping net-pens each year 306 (Glover et al. 2017). In eastern North America, our analysis includes a total of 9236 307 escaped farmed salmon that have been detected since the 1980s, primarily in rivers 308 proximate to the aquaculture industry. This is likely to represent a minimum number of 309 detections since identifying and quantifying escapes will depend on the location, timing, 310 frequency and extent of surveys carried out for this purpose. Information on escaped 311 farmed salmon in eastern North America indicated that rivers in Passamaquoddy Bay, 312 New Brunswick, and southern Newfoundland generally had the highest numbers of 313 escaped farmed salmon. Both areas have high aquaculture production, and high numbers

314 of escaped farmed salmon were previously reported by Morris et al. (2008). The 315 distribution of escaped farmed salmon detected in freshwater has been correlated with the 316 distribution of the industry in both Norway and Scotland (Glover et al. 2017). However, 317 escaped European farmed salmon have also been reported as far away as the Arctic 318 Ocean (Jensen et al. 2013), the Faroe Islands area (Hansen and Jacobsen 2003), and 319 waters of Greenland (Hansen et al. 1997). The distribution of rivers in which escaped 320 farmed salmon were detected here is well within the reported dispersal distance of 321 escaped farmed salmon (Hansen and Youngson 2010) and consistent with previous 322 analyses (i.e. Morris et al. 2008).

323 Admittedly, reports of the presence of escaped farmed salmon are often not an 324 unbiased sample, with opportunistic or targeted non-random sampling the norm.

325 Research and monitoring has also focused primarily on Passamaquoddy Bay (Carr and 326 Whoriskey 2006; O'Reilly et al. 2006; Whoriskey and Carr 2001) and southern

327 Newfoundland due to the concentration of the aquaculture industry and consequent 328 prevalence of escaped farmed salmon in these areas (DFO 2014; Verspoor et al. 2015). 329 For this reason, the current dataset for eastern North America likely lacks sufficient 330 power to detect escaped farmed salmon at low prevalence outside these core areas. 
331 Furthermore, differences in data types and how they were collected means directly 332 comparing counts obtained at the targeted monitoring facilities with intermittent or 333 anecdotal counts (such as those obtained by angling, gillnetting, snorkel counts, etc.) may 334 be difficult. As such, this underscores the need for standardized reporting and sampling 335 methods, such as occurs in Norway (Anon 2017), to better quantify the distribution of 336 escaped farmed salmon across the Northwest Atlantic region. This explains why we 337 reported associations between propagule pressure and reports of escaped farmed salmon 338 at fixed monitoring locations and excluded other data sources. This observation also 339 supports the continued use of genetic monitoring (Bourret et al. 2011; Glover et al. 2017;

340 Wringe et al. in review; Mjolnerod et al. 1997) for impacts to gain a complete 341 understanding of escaped famed salmon distribution and the consequences for wild 342 populations.

343 Accordingly, evidence of genetic impacts due to interbreeding with escaped 344 farmed salmon continues to accumulate on both sides of the North Atlantic (Bourret et al. 345 2011; Glover et al. 2017; Wringe et al. in review; Mjolnerod et al. 1997; Muhlfeld et al. 346 2017). Our observation of a significant association between propagule pressure and the 347 amount of introgression between farmed and wild salmon present supports the use of 348 propagule pressure as a predictor of genetic impacts in wild populations. Similar links 349 between propagule pressure and genetic introgression have been detected elsewhere 350 (Bennett et al. 2010; Consuegra et al. 2011; Lamaze et al. 2012; Marie et al. 2012), 351 supporting the use of propagule pressure as a management tool (Pritchard et al. 2007). 352 Moreover, associations between the incidence of escaped farmed salmon in rivers, and 353 river-specific estimates of temporal genetic change (Glover et al. 2012) and admixture 354 (Glover et al. 2013; Heino et al. 2015; Karlsson et al. 2016) have been reported. Our 355 relationship between the number of escapees detected at counting fences and propagule 356 pressure supports these findings.

357 Interestingly, although evidence of a relationship between the magnitude of 358 genetic introgression and river size has been reported elsewhere (Glover et al. 2012;

359 Glover et al. 2017; Heino et al. 2015; Wringe et al. in review) it was not significant in this 360 study. Glover et al. (2012 and 2013) suggested that this relationship may be explained by 361 larger (more robust) wild populations resisting introgression via increased competition on 
362 the spawning grounds and at juvenile stages. In contrast, our analysis suggests propagule 363 pressure was the dominant factor influencing the amount of introgression detected. We 364 restricted this analysis to the southern Newfoundland region because (1) the availability 365 of industry production data allowed direct inclusion in our calculation of propagule 366 pressure (i.e. rather than presence/absence of stocked sites) and (2) increased divergence 367 between wild and aquaculture salmon associated with a New Brunswick origin of the 368 current domestic line increased the power to quantify levels of introgression with the 369 marker panel used. Extension of the analysis to other regions may be possible in the 370 future with improved industry data and targeted genomic panels (Wringe et al. in review). 371 We suggest that propagule pressure could be a useful step toward the prediction of 372 escaped farmed salmon impacts in Canada. The relationships with propagule pressure 373 would likely benefit from the inclusion of more data, and/or data collected specifically to 374 measure range-wide impacts, as has occurred with success in Norway through a 375 standardized monitoring program and formal risk assessment (Taranger et al. 2015). Error 376 in our study may also be attributed to the geographic distances measured, better 377 resolution of the distances involved or the incorporation of behavioural data on the 378 movements of escaped farmed salmon may improve these relationships. The lack of 379 consistency among available provincial/state inventory and/or stocking license records 380 prevented an in-depth region-wide analysis of aquaculture production in this study.

381 Furthermore, we identified significant differences in escape event reporting requirements 382 across the region. Improved data collection on inventory and reporting requirements for 383 escape events should improve understanding of escaped farmed salmon distribution, 384 behaviour and impacts (Jensen et al. 2010). Despite these challenges, we were able to 385 calculate the propagule pressure variable successfully across the study region. Accurate 386 estimates of propagule pressure could potentially be directly incorporated into spatial 387 planning as a way to mitigate impacts of escaped farmed salmon on wild salmon 388 populations.

389 This study has updated the current knowledge on the distribution and prevalence 390 of escaped farmed salmon in rivers of the Northwest Atlantic, and represents the initial 391 steps in testing the use of a cumulative spatial measure of aquaculture production to 392 predict the impacts of escaped farmed salmon on wild populations. The propagule 
393 pressure associations with impact identified here provide a useful metric that could be

394 integrated into a risk management framework to inform aquaculture management

395 activities and identify mitigation strategies.

\section{Acknowledgements}

399 The authors would like to thank all those individuals that contributed data including

400 Edward Parker, Troy Lyons, David Bean, Gerald (Jeff) Cline, Geoff Perry, Christopher

401 Hendry, Jon Carr, Graham Chafe and Ross Jones. The authors wish to thank two

402 anonymous reviewers for helpful and insightful comments on previous versions of this

403 manuscript. For the genetic analysis, staff of DFO Salmonids section Newfoundland

404 Region were responsible for the collection of juvenile tissue samples and the staff of the

405 Aquatic Biotechnology Laboratory of the Bedford Institute of Oceanography for their

406 work in the SNP genotyping. We thank the associate editor of the Canadian Journal for

407 Fisheries and Aquaculture Sciences, as well as two reviewers for their thoughtful

408 comments on this manuscript. This study was funded through the Program for

409 Aquaculture Regulatory Research of Fisheries and Oceans Canada, and the Genomics

410 Research and Development Initiative of Canada. 


\section{References}

Anon. 2017. Rømt oppdrettslaks i vassdrag i 2016. Rapport fra det nasjonale

overvåkingsprogrammet. Fisken og havet, særnr.2b-2017. URL:

http://hi.no/filarkiv/2017/05/romt_fisk_f_h_2b_2017.

Bennett, S.N., Olson, J.R., Kershner, J.L., and Corbett, P. 2010. Propagule pressure and stream characteristics influence introgression: cutthroat and rainbow trout in British Columbia. Ecol. Appl. 20(1): 263-277.

Bentsen, H.B., and Thodesen, J. 2005. Genetic interactions etween farmed and wild fish, with examples from the Atlantic salmon case in Norway. In Selection and Breeding Programs in Aquaculture. Edited by T. Gjedrem. Springer Netherlands, Dordrecht. pp. 319-334.

Besnier, F., and Glover, K.A. 2013. ParallelStructure: A R package to distribute parallel runs of the population genetics program STRUCTURE on multi-core computers. PLoS One 8(7). Bolstad, G.H., Hindar, K., Robertsen, G., Jonsson, B., Sægrov, H., Diserud, O.H., Fiske, P., Jensen, A.J., Urdal, K., Næsje, T.F., Barlaup, B.T., Florø-Larsen, B., Lo, H., Niemelä, E., and Karlsson, S. 2017. Gene flow from domesticated escapes alters the life history of wild Atlantic salmon. Nature Ecology \& Evolution 1(5): 0124.

Bourret, V., Dionne, M., Kent, M.P., Lien, S., and Bernatchez, L. 2013a. Landscape genomics in Atlantic salmon (Salmo salar): Searching for gene-environment interactions driving local adaptation. Evolution 67(12): 3469-3487.

Bourret, V., Kent, M.P., Primmer, C.R., Vasemägi, A., Karlsson, S., Hindar, K., Mcginnity, P., Verspoor, E., Bernatchez, L., and Lien, S. 2013b. SNP-array reveals genome-wide patterns of geographical and potential adaptive divergence across the natural range of Atlantic salmon (Salmo salar). Mol. Ecol. 22(3): 532-551. 
Bourret, V., O'Reilly, P.T., Carr, J.W., Berg, P.R., and Bernatchez, L. 2011. Temporal change in genetic integrity suggests loss of local adaptation in a wild Atlantic salmon (Salmo salar) population following introgression by farmed escapees. Heredity 106(3): 500-510.

Bradbury, I.R., Hamilton, L.C., Dempson, B., Robertson, M.J., Bourret, V., Bernatchez, L., and Verspoor, E. 2015. Transatlantic secondary contact in Atlantic Salmon, comparing microsatellites, a single nucleotide polymorphism array and restriction-site associated DNA sequencing for the resolution of complex spatial structure. Mol. Ecol. 24(20): 5130-5144. Carr, J.W., Anderson, J.M., Whoriskey, F.G., and Dilworth, T. 1997. The occurrence and spawning of cultured Atlantic salmon (Salmo salar) in a Canadian river. ICES J. Mar. Sci. 54(6): 1064-1073.

Carr, J.W., and Whoriskey, F.G. 2006. The escape of juvenile farmed Atlantic salmon from hatcheries into freshwater streams in New Brunswick, Canada. ICES J. Mar. Sci. 63(7): 12631268.

Chaput, G. 2012. Overview of the status of Atlantic salmon (Salmo salar) in the North Atlantic and trends in marine mortality. ICES Journal of Marine Science 69(9): 1538-1548.

Clifford, S.L., McGinnity, P., and Ferguson, A. 1998. Genetic changes in Atlantic salmon (Salmo salar) populations of northwest Irish rivers resulting from escapes of adult farm salmon. Canadian Journal of Fisheries and Aquatic Sciences 55(2): 358-363.

Colautti, R.I. 2005. Are characteristics of introduced salmonid fishes biased by propagule pressure? Can. J. Fish. Aquat. Sci. 62(4): 950-959.

Consuegra, S., Phillips, N., Gajardo, G., and de Leaniz, C.G. 2011. Winning the invasion roulette: escapes from fish farms increase admixture and facilitate establishment of non-native rainbow trout. Evol. Appl. 4(5): 660-671. 
Copp, G.H., Templeton, M., and Gozlan, R.E. 2007. Propagule pressure and the invasion risks of non-native freshwater fishes: a case study in England. Journal of Fish Biology 71: 148-159. COSEWIC. 2010. COSEWIC assessment and status report on the Atlantic salmon, Salmo salar: Nunavik population, Labrador population, northeast Newfoundland population, south Newfoundland population, southwest Newfoundland population, northwest Newfoundland population, Quebec eastern north shore population, Quebec western north shore population, Anticosti Island population, inner St. Lawrence population, Lake Ontario population, Gaspésouthern gulf of St. Lawrence population, eastern Cape Breton population, Nova Scotia southern upland population, inner Bay of Fundy population, outer Bay of Fundy population, in Canada. Canadian Research Index.

Crozier, W.W. 1993. Evidence of Genetic Interaction between Escaped Farmed Salmon and Wild Atlantic Salmon (Salmo-Salar L) in a Northern Irish River. Aquaculture 113(1-2): 19-29. DFO. 2008. Recovery Potential Assessment for Inner Bay of Fundy Atlantic Salmon. DFO Can. Sci. Advis. Sec. Sci. Advis. Rep. 2008/050.

DFO. 2013. Recovery potential assessment for the south Newfoundland Atlantic salmon (Salmo salar) designatable unit. DFO Can. Sci. Advis. Sec. Sci. Advis. Rep. 2012/007.

DFO. 2014. Stock Assessment of Newfoundland and Labrador Salmon - 2013. DFO Can. Sci. Advis. Sec. Sci. Advis. Rep. 2014/023.

Fiske, P., Lund, R.A., and Hansen, L.P. 2006. Relationships between the frequency of farmed Atlantic salmon, Salmo salar L., in wild salmon populations and fish farming activity in Norway, 1989-2004. ICES J. Mar. Sci. 63(7): 1182-1189. 
Fleming, I.A., Hindar, K., Mjølnerød, I.B., Jonsson, B., Balstad, T., and Lamberg, A. 2000.

Lifetime success and interactions of farm salmon invading a native population. Proc. R. Soc. Lond., Ser. B: Biol. Sci. 267(1452): 1517-1523.

Fleming, I.A., Jonsson, B., Gross, M.R., and Lamberg, A. 1996. An experimental study of the reproductive behaviour and success of farmed and wild Atlantic salmon (Salmo salar). J. Appl. Ecol. 33(4): 893-905.

Ford, J.S., and Myers, R.A. 2008. A global assessment of salmon aquaculture impacts on wild salmonids. PLoS Biol. 6(2): 411-417.

Forseth, T., Barlaup, B.T., Finstad, B., Fiske, P., Gjøsæter, H., Falkegård, M., Hindar, A., Mo, T.A., Rikardsen, A.H., Thorstad, E.B., Vøllestad, L.A., and Wennevik, V. 2017. The major threats to Atlantic salmon in Norway. ICES J. Mar. Sci. 74(6): 1496-1513.

Fraser, D.J., Cook, A.M., Eddington, J.D., Bentzen, P., and Hutchings, J.A. 2008. Mixed evidence for reduced local adaptation in wild salmon resulting from interbreeding with escaped farmed salmon: complexities in hybrid fitness. Evolutionary Applications 1(3): 501-512.

Fraser, D.J., Minto, C., Calvert, A.M., Eddington, J.D., and Hutchings, J.A. 2010. Potential for domesticated-wild interbreeding to induce maladaptive phenology across multiple populations of wild Atlantic salmon (Salmo salar). Can. J. Fish. Aquat. Sci. 67(11): 1768-1775.

Glover, K.A., Pertoldi, C., Besnier, F., Wennevik, V., Kent, M., and Skaala, O. 2013. Atlantic salmon populations invaded by farmed escapees: quantifying genetic introgression with a Bayesian approach and SNPs. Bmc Genet 14.

Glover, K.A., Quintela, M., Wennevik, V., Besnier, F., Sorvik, A.G.E., and Skaala, O. 2012. Three Decades of Farmed Escapees in the Wild: A Spatio-Temporal Analysis of Atlantic Salmon Population Genetic Structure throughout Norway. Plos One 7(8). 
Glover, K.A., Solberg, M.F., McGinnity, P., Hindar, K., Verspoor, E., Coulson, M.W., Hansen, M.M., Araki, H., Skaala, Ø., and Svåsand, T. 2017. Half a century of genetic interaction between farmed and wild Atlantic salmon: Status of knowledge and unanswered questions. Fish Fish. Hansen, L.P., and Jacobsen, J.A. 2003. Origin and migration of wild and escaped farmed Atlantic salmon, Salmo salar L., in oceanic areas north of the Faroe Islands. ICES J. Mar. Sci. 60(1): 110-119.

Hansen, L.P., Jacobsen, J.A., and Lund, R.A. 1999. The incidence of escaped farmed Atlantic salmon, Salmo salar L., in the Faroese fishery and estimates of catches of wild salmon. ICES J. Mar. Sci. 56(2): 200-206.

Hansen, L.P., Reddin, D.G., and Lund, R.A. 1997. The incidence of reared Atlantic salmon (Salmo salar L) of fish farm origin at West Greenland. ICES J. Mar. Sci. 54(1): 152-155. Hansen, L.P., and Youngson, A.F. 2010. Dispersal of large farmed Atlantic salmon, Salmo salar, from simulated escapes at fish farms in Norway and Scotland. Fish. Manage. Ecol. 17(1): 28-32. Heino, M., Svasand, T., Wennevik, V., and Glover, K.A. 2015. Genetic introgression of farmed salmon in native populations: quantifying the relative influence of population size and frequency of escapees. Aquaculture Environment Interactions 6(2): 185-190.

Hess, J.E., Campbell, N.R., Docker, M.F., Baker, C., Jackson, A., Lampman, R., McIlraith, B., Moser, M.L., Statler, D.P., Young, W.P., Wildbill, A.J., and Narum, S.R. 2015. Use of genotyping by sequencing data to develop a high-throughput and multifunctional SNP panel for conservation applications in Pacific lamprey. Molecular Ecology Resources 15(1): 187-202. ICES. 2016. Report of the Working Group on North Atlantic Salmon (WGNAS), Copenhagen, Denmark. 
Jensen, A.J., Karlsson, S., Fiske, P., Hansen, L.P., Hindar, K., and Ostborg, G.M. 2013. Escaped farmed Atlantic salmon grow, migrate and disperse throughout the Arctic Ocean like wild salmon. Aquacult. Env. Interac. 3(3): 223-229.

Jensen, O., Dempster, T., Thorstad, E.B., Uglem, I., and Fredheim, A. 2010. Escapes of fishes from Norwegian sea-cage aquaculture: causes, consequences and prevention. Aquacult. Env. Interac. 1(1): 71-83.

Jones, M.H., Seeb, J.E., Warheit, K.I., Seamons, T.R., Quinn, T.P., and Seeb, L.W. 2015. Consequences of emergence timing for the growth and relative survival of steelhead fry from naturally spawning wild and hatchery parents. Trans. Am. Fish. Soc. 144(5): 977-989.

Jonsson, B., and Jonsson, N. 2006. Cultured Atlantic salmon in nature: a review of their ecology and interaction with wild fish. ICES Journal of Marine Science 63(7): 1162-1181.

Karlsson, S., Diserud, O.H., Fiske, P., and Hindar, K. 2016. Widespread genetic introgression of escaped farmed Atlantic salmon in wild salmon populations. ICES Journal of Marine Science: Journal du Conseil 73(10): 2488-2498.

Lamaze, F.C., Sauvage, C., Marie, A., Garant, D., and Bernatchez, L. 2012. Dynamics of introgressive hybridization assessed by SNP population genomics of coding genes in stocked brook charr (Salvelinus fontinalis). Mol. Ecol. 21(12): 2877-2895.

Larson, W.A., Seeb, J.E., Pascal, C.E., Templin, W.D., and Seeb, L.W. 2014. Single-nucleotide polymorphisms (SNPs) identified through genotyping-by-sequencing improve genetic stock identification of Chinook salmon (Oncorhynchus tshawytscha) from western Alaska. Can. J. Fish. Aquat. Sci. 71(5): 698-708. 
Marie, Amandine D., Bernatchez, L., and Garant, D. 2012. Environmental factors correlate with hybridization in stocked brook charr (Salvelinus fontinalis). Can. J. Fish. Aquat. Sci. 69(5): 884893.

McGinnity, P., Prodöhl, P., Ferguson, K., Hynes, R., Ó Maoiléidigh, N., Baker, N., Cotter, D., O'Hea, B., Cooke, D., Rogan, G., Taggart, J., and Cross, T. 2003. Fitness reduction and potential extinction of wild populations of Atlantic salmon, Salmo salar, as a result of interactions with escaped farm salmon. Proc. R. Soc. Lond., Ser. B: Biol. Sci. 270(1532): 2443-2450.

McGinnity, P., Stone, C., Taggart, J.B., Cooke, D., Cotter, D., Hynes, R., McCamley, C., Cross, T., and Ferguson, A. 1997. Genetic impact of escaped farmed Atlantic salmon (Salmo salar L.) on native populations: use of DNA profiling to assess freshwater performance of wild, farmed, and hybrid progeny in a natural river environment. Ices Journal of Marine Science 54(6): 9981008.

Mjolnerod, I.B., Refseth, U.H., Karlsen, E., Balstad, T., Jakobsen, K.S., and Hindar, K. 1997. Genetic differences between two wild and one farmed population of Atlantic salmon (Salmo salar) revealed by three classes of genetic markers. Hereditas 127(3): 239-248.

Moore, J.S., Bourret, V., Dionne, M., Bradbury, I., O'Reilly, P., Kent, M., Chaput, G., and Bernatchez, L. 2014. Conservation genomics of anadromous Atlantic salmon across its North American range: outlier loci identify the same patterns of population structure as neutral loci. Molecular Ecology 23(23): 5680-5697.

Morris, M.R.J., Fraser, D.J., Heggelin, A.J., Whoriskey, F.G., Carr, J.W., O'Neil, S.F., and Hutchings, J.A. 2008. Prevalence and recurrence of escaped farmed Atlantic salmon (Salmo salar) in eastern North American rivers. Can. J. Fish. Aquat. Sci. 65(12): 2807-2826. 
Muhlfeld, C.C., Kovach, R.P., Al-Chokhachy, R., Amish, S.J., Kershner, J.L., Leary, R.F., Lowe, W.H., Luikart, G., Matson, P., Schmetterling, D.A., Shepard, B.B., Westley, P.A.H., Whited, D., Whiteley, A., and Allendorf, F.W. 2017. Legacy introductions and climatic variation explain spatiotemporal patterns of invasive hybridization in a native trout. Glob Chang Biol 23(11): 4663-4674.

O'Reilly, P.T., Carr, J.W., Whoriskey, F.G., and Verspoor, E. 2006. Detection of European ancestry in escaped farmed Atlantic salmon, Salmo salar L., in the Magaguadavic River and Chamcook Stream, New Brunswick, Canada. ICES J. Mar. Sci. 63(7): 1256-1262.

Parrish, D.L., Behnke, R.J., Gephard, S.R., McCormick, S.D., and Reeves, G.H. 1998. Why aren't there more Atlantic salmon (Salmo salar)? Canadian Journal of Fisheries and Aquatic Sciences 55: 281-287.

Petrou, E.L., Seeb, J.E., Hauser, L., Witteveen, M.J., Templin, W.D., and Seeb, L.W. 2014. Finescale sampling reveals distinct isolation by distance patterns in chum salmon (Oncorhynchus keta) populations occupying a glacially dynamic environment. Conserv. Genet. 15(1): 229-243. Pompanon, F., Bonin, A., Bellemain, E., and Taberlet, P. 2005. Genotyping errors: Causes, consequences and solutions. Nat. Rev. Genet. 6(11): 847-859.

Pritchard, J.K., Stephens, M., and Donnelly, P. 2000. Inference of population structure using multilocus genotype data. Genetics 155(2): 945.

Pritchard, V.L., Jones, K., and Cowley, D.E. 2007. Estimation of introgression in cutthroat trout populations using microsatellites. Conserv. Genet. 8(6): 1311-1329.

R Development Core Team. 2016. R: A language and environment for statistical computing. R Foundation for Statistical Computing, Vienna, Austria.

RStudio Team. 2015. RStudio: Integrated Development for R. RStudio, Inc. 
Schiermeier, Q. 2003. Fish farms' threat to salmon stocks exposed. Nature 425(6960): 753-753. Seeb, J.E., Pascal, C.E., Ramakrishnan, R., and Seeb, L.W. 2009. SNP genotyping by the 5'nuclease reaction: Advances in high-throughput genotyping with nonmodel organisms. In Single Nucleotide Polymorphisms: Methods and Protocols. Edited by A.A. Komar. Humana Press, Totowa, NJ. pp. 277-292.

Skaala, O., Glover, K.A., Barlaup, B.T., Svasand, T., Besnier, F., Hansen, M.M., and Borgstrom, R. 2012. Performance of farmed, hybrid, and wild Atlantic salmon (Salmo salar) families in a natural river environment. Canadian Journal of Fisheries and Aquatic Sciences 69(12): 19942006.

Skaala, O., Wennevik, V., and Glover, K.A. 2006. Evidence of temporal genetic change in wild Atlantic salmon, Salmo salar L., populations affected by farm escapees. Ices Journal of Marine Science 63(7): 1224-1233.

Taranger, G.L., Karlsen, O., Bannister, R.J., Glover, K.A., Husa, V., Karlsbakk, E., Kvamme, B.O., Boxaspen, K.K., Bjorn, P.A., Finstad, B., Madhun, A.S., Morton, H.C., and Svasand, T. 2015. Risk assessment of the environmental impact of Norwegian Atlantic salmon farming. Ices Journal of Marine Science 72(3): 997-1021.

USASAC. 2016. Report No. 28 - 2015 Activities 2007/20, Falmouth, Maine.

Verspoor, E., McGinnity, P., Bradbury, I., and Glebe, B. 2015. The potential direct and indirect genetic consequences for native Newfoundland Atlantic Salmon from interbreeding with European-origin farm escapes. DFO Can. Sci. Advis. Sec. Res. Doc. 2015/030.

Weir, L.K., Hutchings, J.A., Fleming, I.A., and Einum, S. 2005. Spawning behaviour and success of mature male Atlantic salmon (Salmo salar) parr of farmed and wild origin. Can. J. Fish. Aquat. Sci. 62(5): 1153-1160. 
Whoriskey, F.G., and Carr, J.W. 2001. Returns of transplanted adult, escaped, cultured Atlantic salmon to the Magaguadavic River, New Brunswick. ICES J. Mar. Sci. 58(2): 504-509.

\section{Figure captions}

Fig 1. The numbers of escaped farmed salmon detected at counting fences and fishways and propagule pressures in Atlantic rivers. Solid curves show predicted relationships using generalized linear models with Poisson distribution including and excluding the Magaguadavic River (panels A and B respectively). Dashed curves represent 95\% confidence intervals of models. Both models are statistically significant (p-values $<0.001$ ). Point shapes correspond to the province or state of detections. Propagule pressures were calculated region-wide using active (stocked) aquaculture sites from 2005-2015.

Fig 2. Propagule pressures, river sizes, and mean population $Q$ values for Newfoundland rivers (points). Panel A shows log-log regression between propagule pressure and mean Q value ( $\mathrm{p}$ value < 0.01). Panel B shows log-log regression between river size and mean Q value (p-value > 0.05). Propagule pressures were calculated using Newfoundland inventory data (2005-2015) and river sizes are axial lengths $(\mathrm{km})$. Solid curves show predicted effects on response; dashed curves show $95 \%$ confidence intervals. 


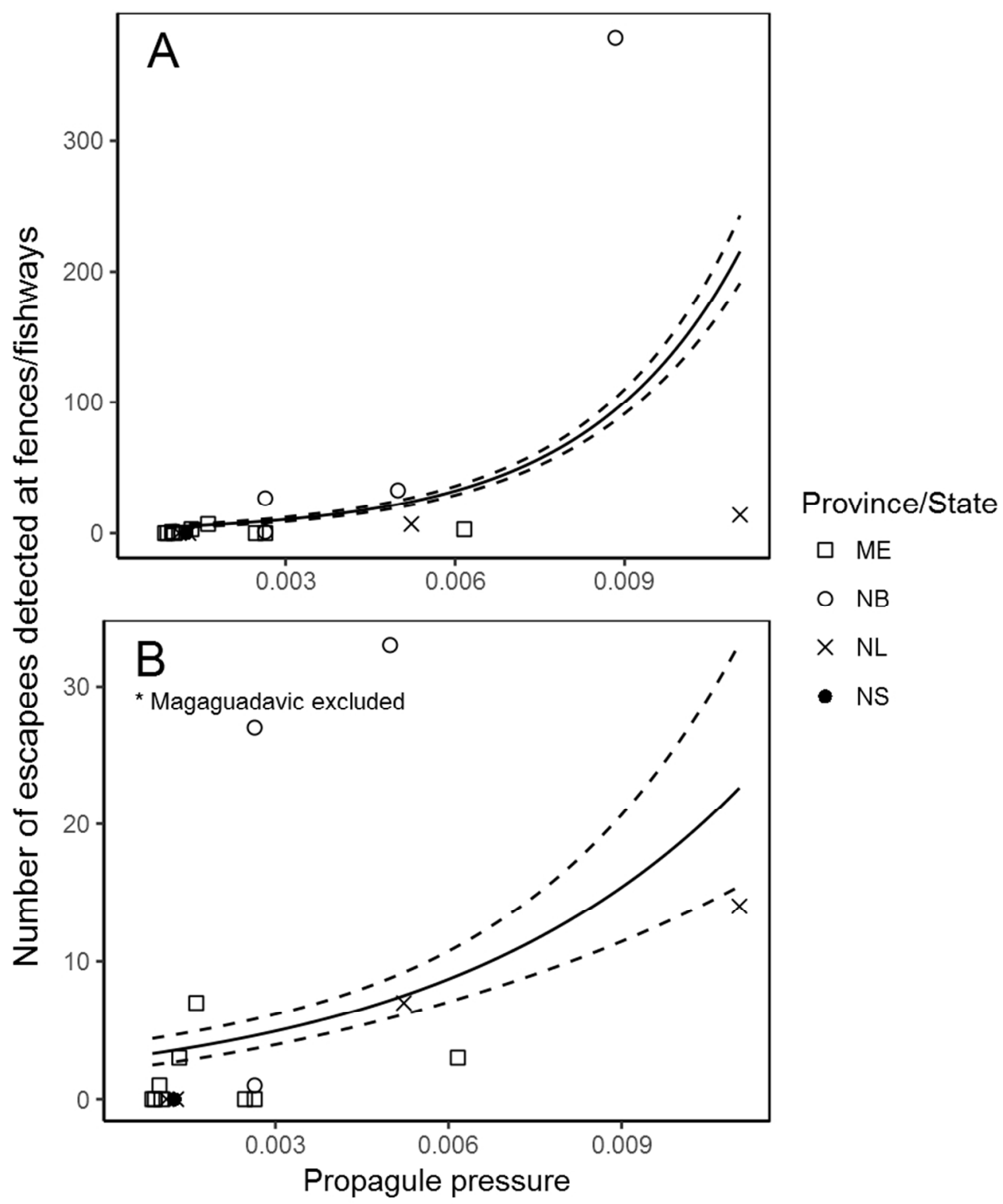

Fig 1. The numbers of escaped farmed salmon detected at counting fences and fishways and propagule pressures in Atlantic rivers. Solid curves show predicted relationships using generalized linear models with Poisson distribution including and excluding the Magaguadavic River (panels A and B respectively). Dashed curves represent $95 \%$ confidence intervals of models. Both models are statistically significant ( $p$-values < 0.001). Point shapes correspond to the province or state of detections. Propagule pressures were calculated region-wide using active (stocked) aquaculture sites from 2005-2015. 


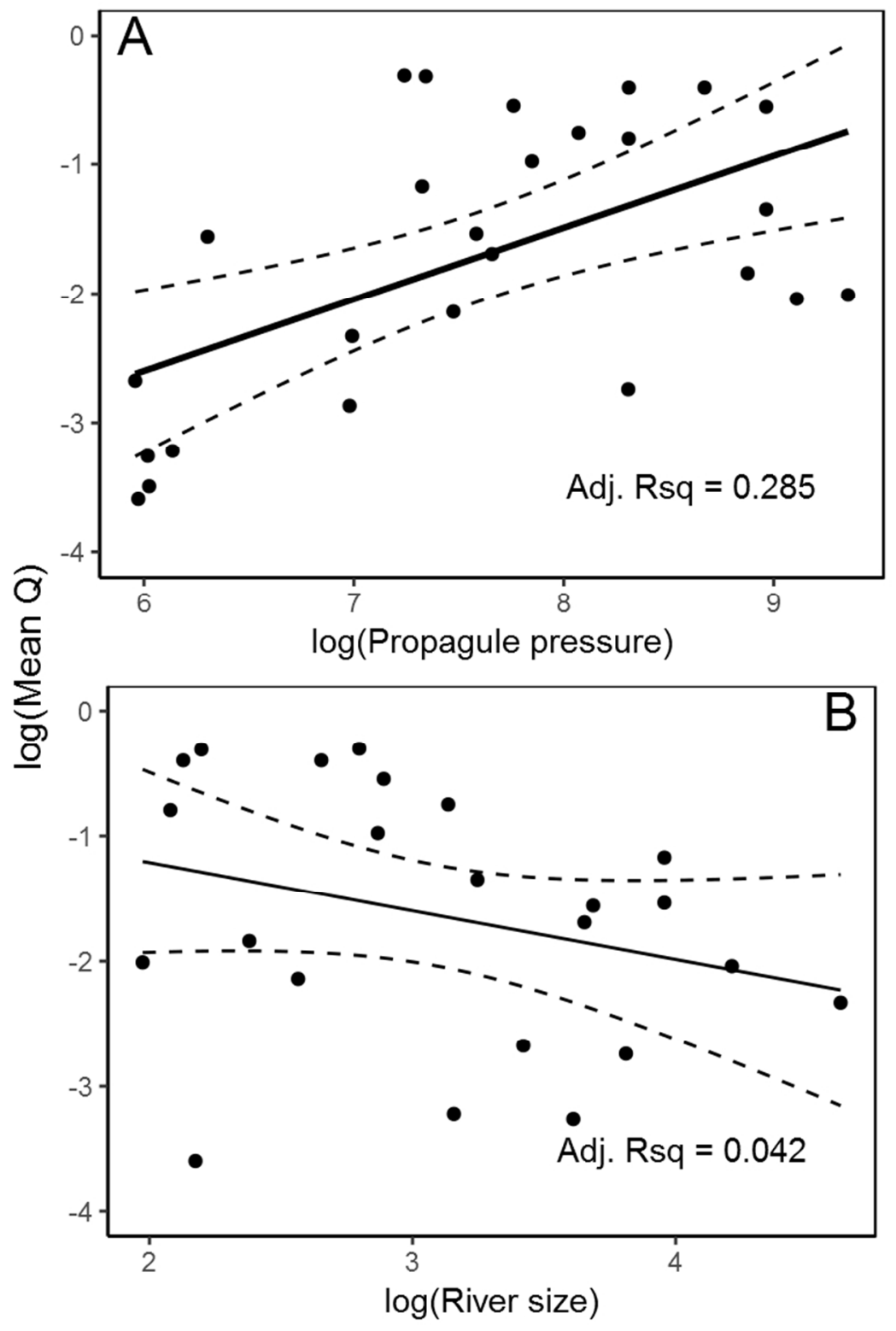

